Short Communication

\title{
Comparative cytogenetics of nine populations of the Rhinella genus (Anura, Bufonidae) with a highlight on their conservative karyotype
}

Daniel Pacheco Bruschi ${ }^{1,2}$ (D), Deborah Yasmim Sousa ${ }^{1}$, Amanda Soares ${ }^{1}$, Klélia Aparecida de Carvalho ${ }^{3}$, Carmen Sílvia Busin ${ }^{4}$, Natália Cristine Ficanha ${ }^{4}$, Albertina Pimentel Lima ${ }^{5}$, Gilda Vasconcellos Andrade ${ }^{6}$ and Shirlei Maria Recco-Pimentel ${ }^{2}$

${ }^{I}$ Departamento de Genética, Setor de Ciências Biológicas, Universidade Federal do Paraná (UFPR), Curitiba, PR, Brazil.

${ }^{2}$ Departamento de Biologia Estrutural e Funcional, Instituto de Biologia, Universidade Estadual de Campinas (UNICAMP), Campinas, SP, Brazil.

${ }^{3}$ Departamento de Genética e Evolução, Microbiologia e Imunologia, Instituto de Biologia, Universidade Estadual de Campinas (UNICAMP), Campinas, SP, Brazil.

${ }^{4}$ Instituto de Ciências Biológicas, Programa de Pós-Graduação em Ciências Ambientais (PPGCiAmb), Universidade de Passo Fundo (UPF), Passo Fundo, RS, Brazil.

${ }^{5}$ Instituto Nacional de Pesquisas da Amazônia (INPA), 69060-001 Manaus, AM, Brazil.

${ }^{6}$ Departamento de Biologia, Centro de Ciências Biológicas e da Saúde, Universidade Federal do Maranhão (UFMA), São Luís, MA, Brazil.

\begin{abstract}
The genus Rhinella is one of the most diverse groups of bufonid toads, currently composed by 93 valid species and naturally distributed throughout different Neotropical ecoregions. Here, we analyze nine Brazilian populations of toads representing species of the Rhinella margaritifera and Rhinella marina groups. These new data include the first description of the $R$. hoogmoedi and $R$. proboscidae karyotypes, as well as other taxonomically unresolved forms. Chromosomal analysis of the populations revealed pronounced chromosomal uniformity $(2 n=22)$, including the diploid number and chromosomal morphology. Three different NOR-bearing chromosomes were identified: in the subterminal region of pair $10 \mathrm{q}$ in $R$. hoogmoedi, Rhinella sp. 1 and Rhinella sp. 2, in subterminal region of $7 \mathrm{p}$ in $R$. proboscidae and Rhinella cf. margaritifera while in $R$. henseli and R. icterica was detected in interstitial region of $7 \mathrm{p}$. Karyotypic uniformity of the genus permits the inference of interspecific chromosome homologies and evolutionary changes in the NOR-bearing chromosome may represent an informative character in species group level. The review of the cytogenetic data of the Rhinella species together with the new karyotypes reported here contributes to the understanding of the chromosomal evolution of these toads, which karyotypes are highly conserved despite the ample distribution of many forms.
\end{abstract}

Keywords: Bufonid toads, nucleolar organizing region, chromosomal evolution.

Received: May 15, 2018; Accepted: July 17, 2018

Cytogenetic data provide a powerful tool for the evaluation of the taxonomic (Cuevas, 2008; Fávero et al., 2011; Funk et al., 2012) and evolutionary relationships (VeigaMenoncello et al., 2014) among anuran species. The understanding of chromosomal characters helps to identify synapomorphies (Cunningham and Cherry, 2004; Targueta et al., 2012; Suárez et al., 2013; Ferro et al., 2018) and homoplasies (Cardozo et al., 2011), and when combined with molecular phylogenetic inferences, these can contrib-

Send correspondence to Daniel Pacheco Bruschi, Laboratório de Citogenética Animal e Mutagênese Ambiental, Universidade Federal do Paraná (UFPR), 81531-980 Curitiba, Paraná, Brazil. E-mail: danielpachecobruschi@gmail.com. ute to the understanding of the role of chromosomal rearrangements in the diversification of a lineage (VeigaMenoncello et al., 2014).

Evolutionary analysis of anuran cytogenetics has provided important additional insights for phylogenetic inferences (Lourenço et al., 2015; Targueta et al., 2018). Recent shifts in analytical approaches have allowed more systematic evaluations, that have traced evolutionary changes in the chromosomal complement (e.g., Lourenço et al., 2008), both within and among anuran groups. However, the lack of cytogenetic data for many groups remains a limiting factor, especially if taking into account the considerable taxonomic richness of the order Anura, which has at least 7,058 
species (sensu Frost, 2019). An interesting example is the genus Rhinella, a cosmopolitan group currently composed of 92 valid species (sensu Frost, 2019), although there is considerable evidence of a number of cryptic species and undescribed taxa (Fouquet et al., 2007a). Most of the species of this genus are arranged in species groups $(R$. crucifer, $R$. festae, $R$. granulosa, R. margaritifera, R. marina, $R$. spinulosa, and $R$. veraguensis), but some taxa have not been assigned to any existing group (Chaparro et al., 2007; Moravec et al., 2014).

Cytogenetic analyses of the genus Rhinella revealed a pronounced chromosomal uniformity, including the diploid number and chromosomal morphology, and some species, such as Rhinella icterica, Rhinella jimi, and Rhinella schneideri, cannot even be distinguished by their C-banding or the distribution of their NOR (Kasahara et al., 1996; Amaro-Ghilardi et al., 2007). However, alternative NORbearing chromosomes have been identified in other species of the genus (Silva, 2010; Baraquet et al., 2011). The present study is based on a compilation of the available chromosomal data for Rhinella, combined with karyotypes obtained from nine Brazilian populations of toads representing species of the Rhinella margaritifera and Rhinella marina groups. These new data include the first description of the karyotypes of two species of the $R$. margaritifera group (Rhinella hoogmoedi and Rhinella proboscidae), as well as other taxonomically unresolved forms.

The specimens and their respective collecting localities are listed in Table 1. The collection of specimens was authorized by SISBIO/Chico Mendes Institute for the Conservation of Biodiversity, through license number 20266-1. Voucher specimens were deposited in the Zoology $\mathrm{Mu}-$ seum (ZUEC) "Prof. Dr. Adão José Cardoso" at Campinas State University (UNICAMP) in Campinas, SP, Brazil. The chromosomal samples were prepared from suspensions of intestinal epithelial cells, following King and Rofe (1976) and Schmid (1978). The chromosomes were stained with $10 \%$ Giemsa or submitted to the Ag-NOR technique (Howell and Black, 1980). The chromosomes were ranked and classified according to the criteria of Green and Session (1991). In addition to these primary data, the Web of Science (Institute of Scientific Information, Thomson Scientific) bibliographic database was searched for all the published cytogenetic data available on the genus Rhinella.

Chromosomal analysis of the nine Rhinella populations revealed conservative karyotype features, beginning with the diploid number $(2 \mathrm{n}=22)$, which was consistent across all species (see Table 2; Figure 1). All karyotypes consist of six metacentric (pairs 1-3, 5, 8 and 9; Fig. 1) and five submetacentric pairs (pairs 4, 6, 7, 10 and 11; Fig.1). While relatively few Rhinella species have been analyzed cytogenetically (Table 2 ), the available data are remarkable for their uniformity, with only metacentric and submetacentric pairs being found in any species. Small differences in the number of metacentric and submetacentric pairs are found in some studies (Amaro-Ghilardi et al., 2008; Baraquet et al., 2011), however, it seems likely that this has been due to the application of different criteria for the classification of the chromosomes, rather than any real variation among species in their karyotypes.

Three different NOR-bearing chromosomes were identified in the present study. In R. hoogmoedi (Bertioga, SP), Rhinella sp. 1 (Bacabeira, MA), and Rhinella sp. 2 (Parque Viruá, RR), the silver impregnation method detected a NOR site in the subterminal region of the long arm of pair 10, while in R. proboscidae (Reserva Ducke, AM) and Rhinella cf. margaritifera (Laranjal do Jari, AP) the NOR was located in the subterminal region of the short arm of the homologs of pair 7 (Figure 2). In two species of the $R$. marina group, Rhinella henseli, and Rhinella icterica, from both Passo Fundo and Sertão (RS), NOR-bearing chromosomes were detected in the interstitial region of the short arm of the homologs of pair 7, in both sampled populations (Figure 2).

A similar degree of uniformity has been observed in inter-population cytogenetic studies of other Rhinella species. For example, considerable karyological uniformity has been found in the $R$. icterica populations from three

Table 1 - Number of Rhinella specimens analyzed and their localities in Brazil.

\begin{tabular}{|c|c|c|c|}
\hline Species & Number of specimens analyzed & Collection locality & Geographical coordinates \\
\hline R. hoogmoedi & $2 \mathrm{M}+3 \mathrm{~F}$ & Bertioga, SP & $23^{\circ} 48^{\prime} 23.15^{\prime \prime} \mathrm{S} ; 46^{\circ} 03^{\prime} 32.23^{\prime \prime} \mathrm{O}$ \\
\hline R. proboscidae & $2 \mathrm{M}+1 \mathrm{~F}$ & Reserva Florestal Adolpho Ducke, Manaus, AM & $2^{\circ} 57^{\prime} 48.04^{\prime \prime} \mathrm{S} ; 59^{\circ} 55^{\prime} 22.20^{\prime \prime} \mathrm{O}$ \\
\hline Rhinella sp. 1 & $2 \mathrm{M}+1 \mathrm{~F}$ & Bacabeira, MA & $2^{\circ} 56^{\prime} 28.32^{\prime \prime} \mathrm{S} ; 44^{\circ} 21^{\prime} 41.35^{\prime \prime} \mathrm{O}$ \\
\hline Rhinella sp. 2 & $5 \mathrm{M}$ & Parque Viruá, RR & $1^{\circ} 17^{\prime} 26.82^{\prime \prime} \mathrm{N} ; 61^{\circ} 09^{\prime} 09.20^{\prime \prime} \mathrm{O}$ \\
\hline Rhinella cf. margaritiffera & $5 \mathrm{M}+1 \mathrm{~F}$ & Laranjal do Jari, AP & $1^{\circ} 05^{\prime} 39.49^{\prime \prime} \mathrm{N} ; 53^{\circ} 13^{\prime} 04.98^{\prime \prime} \mathrm{O}$ \\
\hline R. henseli & $2 \mathrm{M}+5 \mathrm{~F}$ & FLONA,sPasso Fundo, RS & $28^{\circ} 18^{\prime} 59.10^{\prime \prime} \mathrm{S} ; 52^{\circ} 11^{\prime} 26.42^{\prime} \mathrm{O}$ \\
\hline R. henseli & $3 \mathrm{M}+3 \mathrm{~F}$ & Sertão, RS & $28^{\circ} 02^{\prime} 33.46^{\prime \prime} \mathrm{S} ; 52^{\circ} 12^{\prime} 58.56^{\prime \prime O}$ \\
\hline R. icterica & $3 \mathrm{M}+2 \mathrm{~F}$ & FLONA, Passo Fundo, RS & $28^{\circ} 18^{\prime} 59.10^{\prime \prime} \mathrm{S} ; 52^{\circ} 11^{\prime} 26.42^{\prime} \mathrm{O}$ \\
\hline R. icterica & $8 \mathrm{M}$ & Sertão, RS & $28^{\circ} 02^{\prime} 33.46^{\prime \prime} \mathrm{S} ; 52^{\circ} 12^{\prime} 58.56^{\prime \prime} \mathrm{O}$ \\
\hline
\end{tabular}

M: male; F: female 
Table 2 - Detailed cytogenetic data available for species of the Rhinella genus.

\begin{tabular}{|c|c|c|c|c|}
\hline Species & $2 n$ & FN & NOR-bearing chromosome & Reference \\
\hline \multicolumn{5}{|l|}{ R. margaritifera group } \\
\hline R. hoogmoedi & 22 & 44 & St $10(p)$ & Present study \\
\hline R. margaritifera & 22 & 44 & St $10(q)$ & Baldissera et al. (1999) \\
\hline Rhinella sp. 1 & 22 & 44 & St 10(q) & Present study \\
\hline Rhinella sp. 2 & 22 & 44 & St 10(q) & Present study \\
\hline Rhinella cf.margaritifera & 22 & 44 & St 7(p) & Present study \\
\hline R. proboscidea & 22 & 44 & St 7(p) & Present study \\
\hline \multicolumn{5}{|l|}{ R. crucifer group } \\
\hline R. crucifer & 22 & 44 & St $7(p)$ & $\begin{array}{c}\text { Kasahara et al., (1996) } \\
\text { Silva (2010) }\end{array}$ \\
\hline R. ornata & 22 & 44 & St 7(p) & Silva (2010) \\
\hline R. pombali & 22 & 44 & St $7(p)$ & Silva (2010) \\
\hline \multicolumn{5}{|l|}{ R. marina group } \\
\hline R. arenarum & 22 & 44 & Int 7 (p) & $\begin{array}{l}\text { Baldissera et al. (1999) } \\
\text { Baraqueti et al. (2011) }\end{array}$ \\
\hline R. icterica & 22 & 44 & Int 7 (p) & $\begin{array}{l}\text { Kasahara et al. (1996) } \\
\text { Baldissera } \text { et al. (1999) } \\
\text { Azevedo et al. }(2003) \\
\text { Present study }\end{array}$ \\
\hline R. marina & 22 & 44 & Int 7 (p) & Baldissera et al, (1999) \\
\hline R. schneideri & 22 & 44 & Int 7 (p) & $\begin{array}{c}\text { Kasahara et al, (1996) } \\
\text { Azevedo et al. (2003) } \\
\text { Amaro-Ghilardi et al. (2008) } \\
\text { Baraquet et al., (2011) }\end{array}$ \\
\hline R. rubescens & 22 & 44 & Int 7 (p) & Amaro-Ghilardi et al., (2008) \\
\hline R. jimi & 22 & 44 & Int 7 (p) & Amaro-Ghilardi et al. (2008) \\
\hline R. achavali & 22 & 44 & Int $7(p)$ & Kolenc et al. (2013) \\
\hline R. henseli & 22 & 44 & Int 7 (p) & Present study \\
\hline \multicolumn{5}{|l|}{ R. granulosa group } \\
\hline R. granulosa & 22 & 44 & $\operatorname{Ter} 5(\mathrm{q})$ & Baldissera et al. (1999) \\
\hline R. pygmaea & 22 & 44 & $\operatorname{Ter} 5(\mathrm{q})$ & Baldissera et al. (1999) \\
\hline R. fernandezae & 22 & 44 & n.e. & Baraquet et al. (2011) \\
\hline R. spinulosa group & n.e. & n.e. & n.e. & n.e. \\
\hline R. veraguensis group & n.e. & n.e. & n.e. & n.e. \\
\hline R. festae group & n.e. & n.e. & n.e. & n.e. \\
\hline R. achalensis (not assigned to any group) & 22 & 44 & $\operatorname{Int} 10(\mathrm{p})^{*}$ & Baraquet et al. (2011) \\
\hline
\end{tabular}

$\mathrm{q}=$ long arm; $\mathrm{p}=$ short arm; $\mathrm{St}=$ subtelocentric; int =interstitial position; per = pericentromeric position; ter = terminal position in the chromosome; $\mathrm{n} . \mathrm{e} .=$ not examined; *only secondary constriction information.

sites in the Brazilian state of São Paulo (Kasahara et al., 1996; Baldissera et al., 1999; Azevedo et al., 2003) and in the two populations from Rio Grande do Sul (present study). The cururu toad, R. icterica, occurs in southern Brazil, ranging from Rio Grande do Sul in the South to Bahia in the Northeast, as well as Minas Gerais and Goiás, eastern Paraguay, and extending westward to Missiones in Argentina. It is considered a cosmopolitan species, occurring in different habitats and altitudes, including within the Atlantic Forest biome. The cytogenetic data available on the populations of $R$. schneideri, another species distrib- uted widely in South America, indicate a similar pattern of uniformity (Kasahara et al., 1996; Azevedo et al., 2003; Amaro-Ghilardi et al., 2007; Baraquet et al., 2011).

The overview of the data available for the different Rhinella species (Table 2) indicates that the position of the NOR site is relatively stable within phenotypic groups in the genus. The Rhinella species groups are determined based on phenotypic criteria (Frost, 2018), and while the monophyly of the Rhinella granulosa group has received support from molecular phylogenetic analyses (Pereyra et al., 2016), this has not been confirmed in the others. Karyo- 


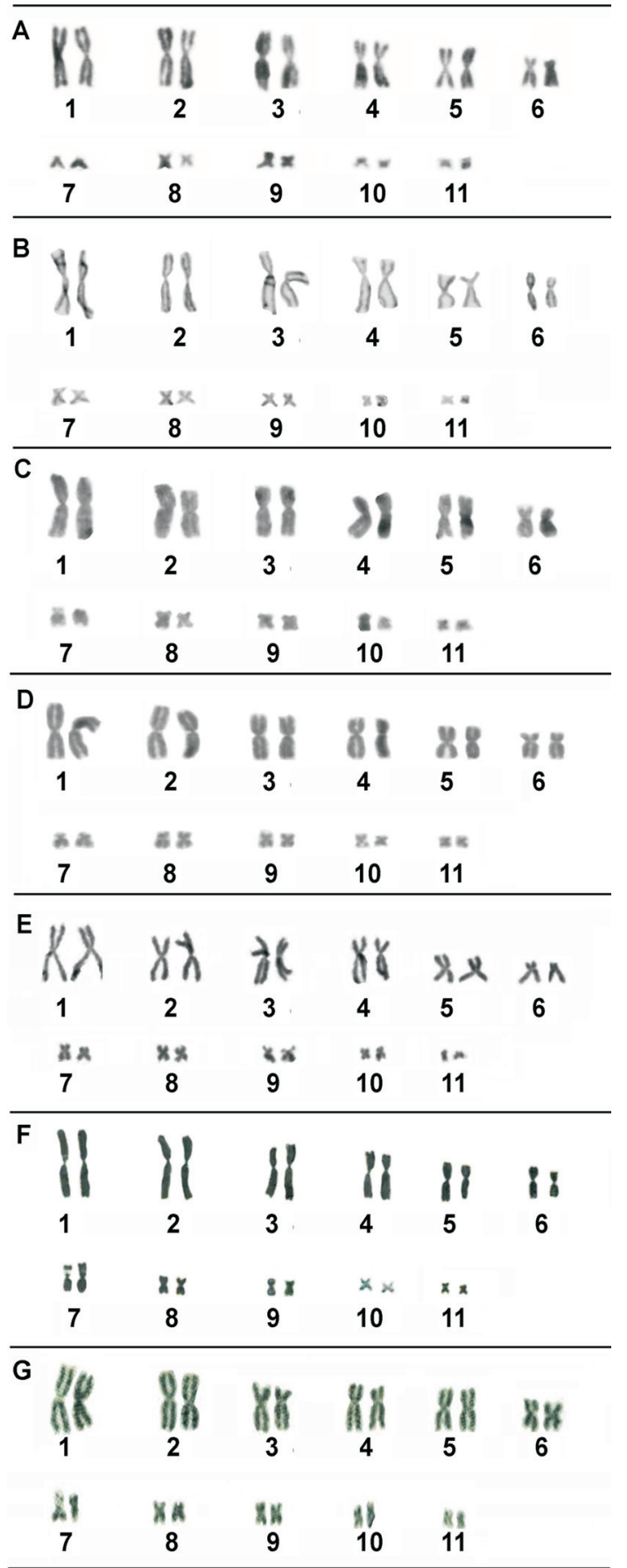

Figure 1 - Karyotypes of five species of the Rhinella margaritifera (A-E) and Rhinella marina (F-G) groups from Brazil, based on Giemsa staining: (A) R. hoogmoedi; (B) R. proboscidae; (C) Rhinella sp. 1; (D) Rhinella sp. 2 and (E) Rhinella cf. margaritifera; (F) R. ictarica from Sertão, RS; (G) $R$. henseli, from Sertão, RS.

type data are available for four of these species groups (Table 2). In all the species of the Rhinella crucifer group, the NOR is found in the subtelocentric region of pair $7 \mathrm{p}$, whereas in the $R$. marina group, it is found in an interstitial region of the $7 \mathrm{p}$, and in the $R$. granulosa group, it is located in the terminal region of the homologs of pair $5 \mathrm{q}$. In the $R$.

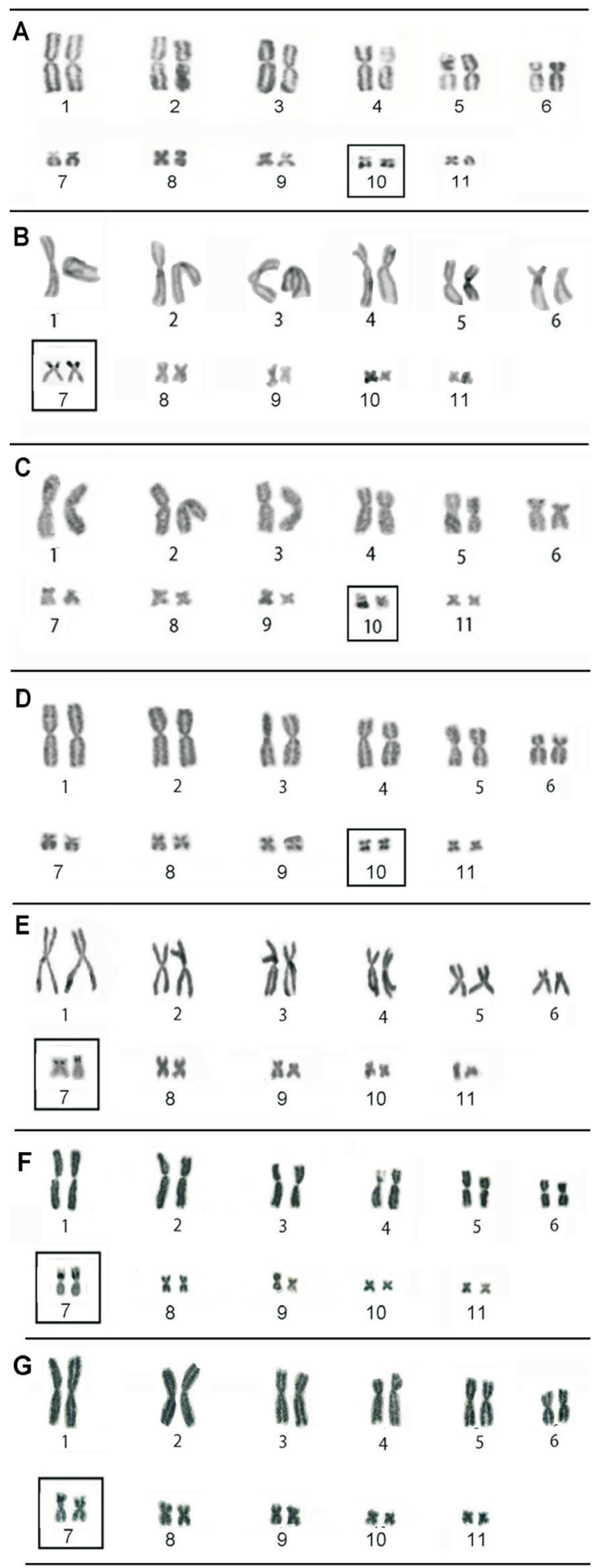

Figure 2 - Karyotypes of five species of the Rhinella margaritifera (A-E) and Rhinella marina (F-G) groups from Brazil stained by the Ag-NOR method: (A) R. hoogmoedi; (B) R. proboscidae; (C) Rhinella sp. 1; (D) Rhinella sp. 2, and (E) Rhinella $\mathrm{cf}$. margaritifera; (F) R. ictarica, from Sertão, RS; (G) R. henseli, from Sertão, RS. The boxes indicate the NOR-bearing chromosomes.

margaritifera group, by contrast, the NOR site is found in the subterminal region of the homologs of pair 10q or the interstitial region of pair $7 \mathrm{p}$ (Table 2). 
As the karyotypic uniformity of the genus permits the inference of interspecific chromosome homologies, it seems reasonable to conclude that the evolutionary changes in the NOR-bearing chromosome may represent a putative synapomorphy in each species group. However, the confirmation of this hypothesis would require the analysis of a much larger dataset, for a more reliable evaluation of potential synapomorphies. If confirmed, the variation in the characteristics of the NOR-bearing chromosomes would provide valuable insights for the understanding of the phylogenetic relationships among the Rhinella species groups. In the $R$. granulosa group, for example, Pereyra et al. (2016) identified NORs in the homologs of pair 5 as an additional synapomorphy in this group. A similar scenario can be inferred for both the $R$. crucifer and $R$. marina groups, but not the $R$. margaritifera group, given the variation already observed in the NOR-bearing chromosomes of the different species of this group.

The $R$. margaritifera group is currently composed of 19 species (Vaz-Silva et al., 2015), with the NOR being found in the homologs of pair 10 (long arm) in $R$. hoogmoedi (present study), and in Rhinella sp. 1 from Maranhão and Rhinella sp. 2 from Roraima. Baldissera et $a l$. (1999) described the karyotype in specimens of the $R$. margaritifera group from Tucuruí, in the Brazilian state of Pará. In the present study, three populations (Rhinella sp. 1, Rhinella sp. 2, and Rhinella cf. margaritifera) were assigned to the $R$. margaritifera group based on morphological and biogeographical criteria, although it was not possible to determine the taxonomic status of these populations based on their karyotypes. Despite their morphological similarities, the Rhinella cf. margaritifera specimens from Laranjal do Jari can be distinguished from all the other populations assigned to the $R$. margaritifera group based on the NOR-bearing chromosome and by phenotypic features (Lima - personal observation), which may indicate the presence of a novel taxonomic entity, which requires further investigation.

The taxonomic status of the species of the $R$. margaritifera group remains uncertain, and phylogenetic inferences indicate the existence of a number of cryptic lineages, and a possible species complex within this group (Fouquet et al., 2007a). This reinforces the need for a thorough taxonomic review of the arrangement of the $R$. margaritifera group in the Amazon region. Molecular approaches have been effectively applied to the recognition and description of many new Rhinella species (Fouquet et al., 2007b; Moravec et al., 2014), and it would almost certainly provide important insights into the delimitation of the species within the $R$. margaritifera group.

The species of the Rhinella margaritifera group are distributed in northern South America and the Central America forest domain, except for $R$. hoogmoedi (Caramaschi and Niemeyer, 2003), which inhabits the Atlantic Forest biome, and $R$. scitulla, $R$. ocellata, $R$. sebbeni, and $R$. paraguayensis, which occur in the Brazilian Cerrado savanna (Ávila et al., 2010; Vaz-Silva et al., 2015). However, the forest-dwelling species tend to present high levels of individual variation in morphological features, which limits the usefulness of these attributes for the discrimination of species. Santos et al. (2015) identified populations from western Ecuador and Panama, frequently assigned to $R$. margaritifera species, as $R$. alata, which has helped to resolve the confusing zoogeography of the $R$. margaritifera complex. However, the status of the populations of the $R$. margaritifera group from the east of the Andes remains unresolved, and the phylogenetic inferences of Fouquet et al. (2007a) indicated the potential existence of at least five distinct taxa identified as $R$. margaritifera in Brazil and French Guiana.

The $R$. proboscidae karyotype is described here for the first time, and it presents a NOR on the homologs of pair 7 , a condition different from that of the other species of the $R$. margaritifera group. While the taxonomy and arrangement of the species in this group are complex (Fouquet et $a l ., 2007 \mathrm{a})$, it has been diagnosed by the presence of an expansion of the posterior ramus of the pterygoid (Pramuk, 2006), a putative morphological synapomorphy that supports the $R$. margaritifera group. However, this putative phenotypic synapomorphy has not been formally tested. Rhinella proboscidae occurs along the Amazon River between Peru and Manaus, in Brazil, the locality sampled in the present study. The morphological characters of these populations support their inclusion in the $R$. margaritifera group. In contrast with the other species groups, however, in which the NOR-bearing chromosome represents a putative synapomorphy, two distinct scenarios are equally possible for the R. margaritifera group: (1) the NOR on pair 10 is a chromosomal synapomorphy in this group and the NOR on pair 7 of $R$. proboscidae represent a character reversion; or (2) the retention of an ancestral polymorphism. Unfortunately, the lack of a complete phylogenetic reconstruction that includes representatives of all the Rhinella groups hampers more conclusive inferences on the chromosomal evolution of this genus. In the specific case of the $R$. margaritifera group, a more systematic analysis of monophyly based on the investigation of specific molecular markers would likely provide decisive insights into the evolution of this group.

The conservative arrangement of the NOR-bearing chromosomes in the different Rhinella groups highlights the potential contribution of cytogenetic data for the identification of diagnostic synapomorphies in species groups or clades. A similar approach has been applied successfully in other amphibian groups (see Grant et al., 2017; Targueta et al., 2018). For example, comparative cytogenetics and the allocation of chromosomal characters (morphology and NOR sites) in a phylogenetic tree inferred from molecular markers allowed Cardozo et al. (2011) to identify three potential synapomorphies in the genus Ololygon (Scinax 
catharinae clade - Duellman et al., 2016). Lourenço et al. (2015) also identified the interstitial C-band in chromosome pair 5 as a synapomorphy of the Physalaemus cuvieri species group.

Another relevant feature of Rhinella genus is the high frequency of hybridization and introgression events (Azevedo et al., 2003; Narvaes and Rodrigues 2009; Sequeira et al., 2011; Guerra et al., 2011; Pereyra et al., 2015) in areas of sympatry, mainly in the Rhinella marina group. As chromosomal features may represent important pre- or postzygotic barriers to reproduction, groups with a uniform karyotype, such as those found in Rhinella, may reflect the relaxation of any isolation mechanism, which would further contribute to the high frequency of hybridization events observed in this genus. For example, Azevedo et al. (2003) identified an intermediate form between Rhinella icterica and Rhinella schneideri in a sympatric zone, based on the banding patterns of seroproteins analyzed by electrophoresis, even though the intermediate form presented no modification of the karyotype in comparison with the parental species.

Overall, it is hoped that this review of the cytogenetic data available for the Rhinella species, together with the new karyotypes reported here, will contribute to the understanding of the mechanisms of evolutionary changes that led to the diversification of these toads. Despite the ample distribution of many forms, karyotypes are highly conserved in most cases.

\section{Acknowledgments}

We thank the Fundação de Amparo a Pesquisa do Estado de São Paulo (FAPESP 2016/07717-6), Coordenação de Aperfeiçoamento de Pessoal de Nível Superior (CAPES/PROAP - Finance Code 001) for the scholarships provided to DYS and AAS, and Conselho Nacional de Desenvolvimento Científico e Tecnológico (CNPq/PQ/312286/2015-5).

\section{Conflict of interest}

The authors declare that they have no competing interests.

\section{Author contributions}

DPB conduced the experiments, conceived and designed the study and wrote; DYS, AS and NCF analyzed the data; APL and GVA collected specimens and helped to identify the specimens; KAC processed material of specimens; CSB and SMR designed the study and wrote the manuscript. All authors read and approved the final version.

\section{References}

Amaro-Ghilardi RC, Silva MJ, Rodrigues MT and YonenagaYassuda Y (2007) Chromosomal studies in four species of genus Chaunus (Bufonidae, Anura): localization of telomeric and ribosomal sequences after fluorescence in situ hybridization (FISH). Genetica 134:159-168.

Ávila RW, Pansonato A and Strüssmann C (2010) A new species of the Rhinella margaritifera group (Anura: Bufonidae) from Brazilian Pantanal. Zootaxa 2339:57-68.

Azevedo MFC, Foresti, F, Ramos PRR and Jim J (2003) Comparative cytogenetic studies of Bufo ictericus, B. paracnemis (Amphibia, Anura) and an intermediate form in sympatry. Genet Mol Biol 26:289-294.

Baldissera FA, Batistic RF and Haddad CFB (1999) Cytotaxonomic considerations with the description of two new NOR locations for South American toads, genus Bufo (Anura: Bufonidae). Amphibia-Reptilia 20:413-420.

Baraquet M, Valetti JA, Salas N and Martino A (2011) Redescription of the karyotypes of five species of the family Bufonidae (Amphibia: Anura) from central area of Argentina. Biologia 66:543-547.

Caramaschi U and Niemeyer H (2003) Nova espécie do complexo de Bufo margaritifer (Laurenti, 1768) do Estado do Mato Grosso do Sul, Brasil (Amphibia, Anura, Bufonidae). Bol Mus Nac Sér Zool 501:1-16.

Cardozo DE, Leme DM, Bortoleto JF, Catroli GF, Baldo D, Faivovich J, Kolenc F, Silva APZ, Borteiro C, Haddad CFB et al. (2011) Karyotypic data on 28 species of Scinax (Amphibia: Anura: Hylidae): diversity and informative variation. Copeia 2:251-263.

Chaparro JC, Pramuk JB and Gluesenkamp AG (2007) A new species of arboreal Rhinella (Anura: Bufonidae) from cloud forest of southeastern Peru. Herpetologica 63:203-212.

Cuevas CC (2008) A new species of the genus Alsodes (Anura: Neobatrachia) from the Nothofagus forest, Coastal Range, Southern Chile, identified by its karyotype. Zootaxa 1771:43-53.

Cunningham MJ and Cherry MI (2004) Molecular systematics of African 20-chromosome toads (Anura: Bufonidae). Mol Phylogenet Evol 32:671-685.

Duellman WE, Marion AB and Hedges SB (2016) Phylogenetics, classification, and biogeography of the treefrogs (Amphibia: Anura: Arboranae). Zootaxa 4104:1-109.

Fávero ER, Veiga-Menoncello ACP, Rossa-Feres DC, Strüssmann C, Giaretta AA, Andrade GV, Colombo P and Recco-Pimentel SM (2011) Intrageneric karyotypic variation in Pseudopaludicola (Anura: Leiuperidae) and its taxonomic relatedness. Zool Stud 50:826-836.

Ferro JM, Cardozo DE, Suárez P, Boeris JM, Blasco-Zúniga A, Barbero G, Gomes A, Gazoni T, Costa W, Nagamachi CY et al. (2018) Chromosome evolution in Cophomantini (Amphibia, Anura, Hylinae). PLoS One 13:e0192861.

Fouquet A, Gilles A, Vences M, Marty C, Blanc M and Gemmell $\mathrm{NJ}$ (2007a) Underestimation of species richness in Neotropical frogs revealed by rDNA analyses. PLoS One 2:e1109.

Fouquet A, Vences M, Salducci MD, Meyer A, Marty C, Blanc M and Gilles A (2007b) Revealing cryptic diversity using molecular phylogenetics and phylogeography in frogs of the Scinax ruber and Rhinella margaritifera species groups. Mol Phylogenet Evol 43:567-682. 
Funk WC, Caminer M and Ron SR (2012) High levels of cryptic species diversity uncovered in Amazonian frogs. Proc R Soc B Biol Sci 279:1806-1814.

Grant T, Rada, M, Anganoy-Criollo M, Batista A, Dias PH, Jeckel AM, Machado DJ and Rueda-Almonacid JV (2017) Phylogenetic systematics of dart poison frogs and their relatives revisited (Anura: Dendrobatoidea). South Am J Herpetol 12:1-90.

Green DM and Sessions SK (1991) Amphibian Cytogenetics and Evolution. Academic Press, San Diego, 456 p.

Guerra C, Baldo D, Rosset S, Borteiro C and Kolenc F (2011) Advertisement and release calls in Neotropical toads of the Rhinella granulosa group and evidence of natural hybridization between $R$. bergi and $R$. major (Anura: Bufonidae). Zootaxa 3092:26-42.

Howell WM and Black DA (1980) Controlled silver staining of nucleolar organizer regions with a protective colloidal developer: A 1 step method. Experientia 36:1014-1015.

Kasahara S, Silva APZ and Haddad CFB (1996) Chromossome banding in three species of Brazilian toads (Amphibia-Bufonidae). Braz J Genet 19:237-242.

King M and Rofe R (1976) Karyotypic variation in the Australian gecko Phyllodactylus marmoratus (Gray) (Gekkonidae, Reptilia). Chromosoma 54:75-87.

Kolenc F, Borteiro C, Cotichelli L, Baldo D, Debat CM and Candioti FV (2013) The tadpole and karyotype of Rhinella achavali (Anura: Bufonidae). J Herpetol 47:599-606.

Lourenço LB, Bacci Jr. M, Martins VG, Recco-Pimentel SM and Haddad CFB (2008) Molecular phylogeny and karyotype differentiation in Paratelmatobius and Scythrophrys (Anura, Leptodactylidae). Genetica 132:255-266.

Lourenço LB, Targueta CP, Baldo D, Nascimento J, Garcia PCA, Andrade GV, Haddad CFB and Recco-Pimentel SM (2015) Phylogeny of frogs from the genus Physalaemus (Anura, Leptodactylidae) inferred from mitochondrial and nuclear gene sequences. Mol Phylogenet Evol 92:204-216.

Moravec J, Lehr E, Cusi JC, Córdova JH and Gvodík V (2014) A new species of the Rhinella margaritifera species group (Anura, Bufonidae) from the montane forest of the Selva Central, Peru. ZooKeys 371:35-56.

Narvaes P and Rodrigues MT (2009) Taxonomic revision of Rhinella granulosa species group (Amphibia, Anura, Bufonidae), with a description of a new species. Arq Zool 40:1-73.

Pereyra MO, Baldo D, Blotto BL, Iglesias PP, Thomé MTC, Haddad CFB, Barrio - Amorós C, Ibáñez R and Faivovich J (2015) Phylogenetic relationships of toads of the Rhinellagranulosa group (Anura: Bufonidae): A molecular perspective with comments on hybridization and introgression. Cladistics 32:36-53.

Pramuk JB (2006) Phylogeny of South American Bufo (Anura: Bufonidae) inferred from combined evidence. Zool J Linn Soc 146:407-452.
Santos SP, Ibáñez R and Ron SR (2015) Systematics of the Rhinella margaritifera complex (Anura, Bufonidae) from western Ecuador and Panama with insights in the biogeography of Rhinella alata. Zookeys 501:109-145.

Schmid M (1978) Chromosome banding in Amphibia. II. Constitutive heterochromatin and nucleolus organizer regions in Ranidae, Microhylidae and Rhacophoridae. Chromosoma 68:131-148.

Sequeira F, Sodré D, Ferrand N, Bernardi JAR, Sampaio I, Schneider H and Vallinoto M (2011) Hybridization and massive mtDNA unidirectional introgression between the closely related Neotropical toads Rhinella marina and $R$. schneideri inferred from mtDNA and nuclear markers. BMC Evol Biol 11:264.

Silva DJS (2010) Análise citogenética e morfométrica em populações de Rhinella pombali (Baldissera Jr., Caramaschi e Haddad, 2004) e Rhinella crucifer (Wied- Neuwied, 1821) (Anura, Bufonidae). M. Sc. Thesis, Universidade Federal de Viçosa, Viçosa.

Suárez P, Cardozo D, Baldo D, Pereyra MO, Faivovich J, Orrico VGD, Catroli GF, Grabiele M, Bernarde PS, Nagamachi C et al. (2013) Chromosome evolution in Dendropsophini (Amphibia, Anura, Hylinae). Cytogenetics Genome Res 141:295-308.

Targueta CP, Rivera M and Lourenço LB (2012) Karyotypic differentiation via $2 \mathrm{n}$ reduction and a finding of a case of triploidy in anurans of the genus Engystomops (Anura, Leiuperidae). Genetica 139:1339-1347.

Targueta CP, Vittorazzi SE, Gatto KP, Bruschi DP, VeigaMenoncello ACP, Recco-Pimentel SMR and Lourenço LB (2018) Anuran cytogenetics: An overview. In: Norris N and Miller C (eds) An Essential Guide to Cytogenetics. Nova Science Publishers, New York, pp 1-64.

Veiga-Menoncello ACP, Lourenço LB, Strussmann C, RossaFeres DC, Andrade GV, Giaretta A and Recco-Pimentel SM (2014) A phylogenetic analysis of Pseudopaludicola (Anura) providing evidence of progressive chromosome reduction. Zool Scripta, 43:261-272.

Vaz-Silva W, Maciel NM, Bastos RP and Pombal Jr JP (2015) Revealing two new species of the Rhinella margaritifera species group (Anura, Bufonidae): An enigmatic taxonomic group of Neotropical toads. Herpetologica, 71:212-222.

\section{Internet resources}

Frost DR (2019) Amphibian Species of the World: an Online Reference. American Museum of Natural History, New York, USA. http://research.amnh.org/herpetology/amphibia/index.html (April 27, 2019).

\section{Associate Editor: Yatiyo Yonenaga-Yassuda}

License information: This is an open-access article distributed under the terms of the Creative Commons Attribution License (type CC-BY), which permits unrestricted use, distribution and reproduction in any medium, provided the original article is properly cited. 